\title{
Effects of probiotic supplementation on markers of skeletal muscle damage, perceived recovery and athletic performance after an intense single leg training bout
}

\author{
Ralf Jäger ${ }^{1 *}$, Kevin Shields ${ }^{2}$, Matthew Sharp², Jeremey Partl', Jacob M Wilson², Ryan P Lowery²,
} Eduardo O De Souza², Chase Holmer², Martin Purpura'

From The Twelfth International Society of Sports Nutrition (ISSN) Conference and Expo Austin, TX, USA. 11-13 June 2015

\section{Introduction}

The probiotic GanedenBC ${ }^{30}$ (Bacillus coagulans GBI-30, 6086; Ganeden Biotech Inc., Maryfield Heights, $\mathrm{OH}$ ) has been shown to support healthy digestive and immune function, including increased protein absorption. In a pilot study, daily co-administration of Ganeden $\mathrm{BC}^{30}$ and protein in resistance-trained subjects performing full body workouts 4 times per week for 8 weeks has shown a trend to increase vertical jump power and might have a beneficial effect on peak power and fat mass. We speculate that the beneficial effects might be based on aiding muscle recovery through gut microbial modulation. Thus, the purpose of this investigation was to determine if the co-administration of GanedenBC ${ }^{30}$ with protein has a beneficial effect on muscle damage, recovery and athletic performance following a damaging exercise bout.

\section{Methods}

30 healthy recreationally-trained males participated in this study (mean+/-SD; age: $21.5 \pm 2.8$ years; height: $177.4 \pm 8.0 \mathrm{~cm}$; weight: $89.7 \pm 28.2 \mathrm{~kg}$ ). Subjects were randomly assigned to consume either $20 \mathrm{~g}$ of casein $($ Control $=\mathrm{CON})$ or $20 \mathrm{~g}$ of casein plus probiotic (500M CFU GanedenBC ${ }^{30}$, = BC30) twice daily in a crossover, diet-controlled design for a two-week time period. Subjects performed a damaging exercise bout consisting of 10 sets $\times 10$ repetitions unilateral leg press at $70 \% 1$ RM with 1 minute rest, one legged - leg extension (5 sets

* Correspondence: ralf.jaeger@increnovo.com

${ }^{1}$ Increnovo LLC, 2138 E Lafayette PI, Milwaukee, WI 53202, USA

Full list of author information is available at the end of the article $\times 12$ reps), and rear foot elevated split squat 5 sets $\times 12$ reps with one minute rest at baseline and after two weeks of supplementation. Athletic performance consisting of peak power (Wingate 10 sec Peak Power Assessment at $7.5 \% \mathrm{BW}$ at $175 \mathrm{RPM}$ threshold loaded drop), vertical jump power (Tendo unit, single-leg jump), and 1-RM single-leg press; and muscle damage was analyzed by muscle swelling (ultrasonography) and blood draws (creatine kinase (CK), blood urea nitrogen (BUN)) were taken at baseline (pre-supplementation) and 48 hours after damaging exercise bout. Perceptual measures (perceived recovery, soreness) were taken before, 24,48 and 72 hours after exercise.

\section{Results}

The damaging exercise bout significantly increased muscle soreness $(\mathrm{p}<0.001)$, reduced perceived recovery $(\mathrm{p}<$ 0.001 ), however, BC30 significantly increased recovery at 24 and 72 hours, and decreased soreness at 72 hours post exercise in comparison to CON. Perceptual measures were confirmed by increases in CK (CON: $+266.8 \%$, $\mathrm{p}=$ 0.0002; $\mathrm{BC} 30:+137.7 \%, \mathrm{p}=0.01)$, with $\mathrm{BC} 30$ showing a trend towards reduced indices of muscle damage $(\mathrm{p}=$ $0.08)$. The strenuous exercise significantly reduced athletic performance in CON (Wingate Peak Power; CON: (-39.8 watts, $-5.3 \%, \mathrm{p}=0.03)$ ), whereas $\mathrm{BC} 30$ maintained performance by $(+10.1$ watts, $+1.7 \%)$. There were no differences between groups for strength responses $(\mathrm{CON}:+7.2 \mathrm{~kg}$, $+2.6 \%, \mathrm{p}=0.15$; and BC30: $+3.4 \mathrm{~kg},+1.2 \%, \mathrm{p}=0.79$ ). 


\section{Conclusions}

This study indicated that probiotic supplementation in form of GanedenBC ${ }^{30}$ in combination with protein (casein) reduces indices of muscle damage, increases recovery and may maintain athletic performance after muscle damaging exercise.

\section{Acknowledgements}

Supported by Ganeden Biotech Inc., Maryfield Heights, $\mathrm{OH}$.

\section{Authors' details}

'Increnovo LLC, 2138 E Lafayette PI, Milwaukee, WI 53202, USA. ²Department

of Health Sciences and Human Performance, The University of Tampa, 401

W. Kennedy Blvd., Tampa, FL 33606, USA

Published: 21 September 2015

doi:10.1186/1550-2783-12-S1-P36

Cite this article as: Jäger et al:: Effects of probiotic supplementation on markers of skeletal muscle damage, perceived recovery and athletic performance after an intense single leg training bout. Journal of the International Society of Sports Nutrition 2015 12(Suppl 1):P36.

Submit your next manuscript to BioMed Central and take full advantage of:

- Convenient online submission

- Thorough peer review

- No space constraints or color figure charges

- Immediate publication on acceptance

- Inclusion in PubMed, CAS, Scopus and Google Scholar

- Research which is freely available for redistribution

Submit your manuscript at www.biomedcentral.com/submit 